\title{
CAMELLIA FLOWER BLIGHT (CIBORINIA CAMELLIAE Kohn) - A NEW DISEASE OF CAMELLIA IN NEW ZEALAND
}

\author{
T.M. STEWART and H. NEILSON
}

Department of Plant Science, Massey University, Palmerston North

\begin{abstract}
Camellia flowerblight, caused by Ciborinia camelliae was found in a Wellington garden in August 1993. Mycological features ofthe fungus isolated matched published descriptions and infectivity tests on fresh camellia blooms confirmed pathogenicity. A survey by MAFQUAL soon after the discovery, showed the pathogen was widespread in the Wellington area. There have been no reports of the disease in other regions. The pathogen attacks only flower tissue. Symptoms first appear as small, irregular brown specks. These soon enlarge and coalesce to form extensive lesions which eventually cover entire petals and finally complete flowers, a process which can happen within 3 days. Infective conidia are not produced on blossoms but sclerotia develop on fallen blooms. These sclerotia give rise to apothecia during the next flowering season, hence there are no secondary infection cycles. There appear to be no resistant varieties of Camellia japonica. Control of this pathogen is primarily by cultural means and by exclusion, although biological control measures are being explored. Public education is required to prevent the disease spreading to other parts of New Zealand.
\end{abstract}

\section{POPULATION DYNAMICS ON APPLE BLOSSOMS OF THREE BIOLOGICAL CONTROL AGENTS OF FIRE BLIGHT SPRAYED ALONE AND IN COMBINATION}

\author{
DARIENNE VOYLE, JANET YU and JOEL L. VANNESTE
}

\section{HortResearch, Ruakura Research Centre, Private Bag 3123, Hamilton}

Three biocontrol agents (BCAs), Pseudomonas fluorescens A506, Erwinia herbicola C9-1 and E. herbicola Eh252, were tested for compatability on apple flowers, the main port of entry of the fire blight pathogen. These BCAs have different climatic requirements for optimum growth and inhibit the pathogen by different mechanisms. Royal Gala and Braeburn flowers were sprayed with bacterial suspensions of each BCA, separately or eachpossible combination oftwo at equal rates. Populations of these bacteria on stigmas and nectaries were estimated for seven days. On nectaries of both cultivars, populations of all BCAs fluctuated widely, so no comparison was possible. On stigmas of both cultivars, populations of all strains reached $1 x 1 \mathrm{cfu} /$ flower when sprayed alone. No difference was detected in the population levels and growth rates of any of the BCAs tested, when sprayed alone or together, except for C9- I when sprayed with Eh252. On Braeburn, from day 2 the C9-1 population was ten times less than when sprayed alone. On Royal Gala, where the C9- I inoculum was one hundred times lower than that of the other BCAs, the C9-1 population declined from day 2 until it was, on day seven, 1000 times less than when sprayed alone. It seems that when two E. herbicola are sprayed together, one is inhibited, but when one of the E. herbicola is mixed with the $P$. fluorescens, no obvious inhibition is detected. 